\title{
EROD activities in a primary cell culture of grass carp (Ctenopharyngodon idellus) hepatocytes exposed to polychlorinated aromatic hydrocarbonas
}

\author{
Xiaoqiong Wan, ${ }^{\mathrm{a}, \mathrm{b}, *}$ Taowu Ma, ${ }^{\mathrm{a}}$ Wenzhong Wu, ${ }^{\mathrm{b}}$ and Zijian Wang ${ }^{\mathrm{a}, 1}$ \\ ${ }^{a}$ Research Center for Eco-environmental Sciences, State Key Laboratory of Environmental Aquatic Chemistry, Chinese Academy of Sciences, \\ P.O. Box. 2871, Beijing 100085, China \\ ${ }^{\mathrm{b}}$ Institute of Hydrobiology, State Key Laboratory for Freshwater Ecology and Biotechnology, Chinese Academy of Sciences, Wuhan 430072, China
}

Received 23 September 2002; received in revised form 16 January 2004; accepted 28 January 2004

\begin{abstract}
Aryl hydrocarbon (Ah) receptor (Ah-agonist) effects of environmental samples containing polychlorinated aromatic hydrocarbons were evaluated using a 7-ethoxyresorufin- $O$-deethylase (EROD) assay of a primary hepatocyte culture from grass carp (Ctenopharyngodon idellus). The results were compared with those obtained from the assay using the rat hepatoma cell line H4IIE and chemical analysis using high-resolution gas chromatography/high-resolution mass spectrometry (HRGC/HRMS). A dose-response relationship was observed between the EROD activities, either from primary hepatocyte culture assay or from H4IIE assay, and concentrations of 2,3,7,8-tetrachlorodibenzo-p-dioxin (TCDD). The results showed that the assay based on the H4IIE cell line $\left(\mathrm{EC}_{50}=0.83 \mathrm{pg} / \mathrm{mL}\right)$ is more sensitive to TCDD than the assay based on primary hepatocyte culture $(\mathrm{EC} 50=9.7 \mathrm{pg} / \mathrm{mL})$. In tests of environmental samples, the results from the assay using primary hepatocyte culture were comparable to those from the assay using the H4IIE cell line and chemical analysis of concentrations of mixtures of polychlorinated dibenzo- $p$-dioxin and dibenzofuran (PCDD/PCDF). The lack of a change in the activities of glutathione- $S$-transferase (GST) and lactate dehydrogenase (LDH) in cell culture upon exposure to TCDD indirectly indicates that the compound is persistent to biodegradation in the cell culture system. (C) 2004 Elsevier Inc. All rights reserved.
\end{abstract}

Keywords: Primary hepatocyte culture; EROD; Grass carp (Ctenopharyngodon idellus); Polychlorinated aromatic hydrocarbons

\section{Introduction}

Polycyclic aromatic hydrocarbons (PAHs) and planar polyhalogenated compounds such as polychlorinated biphenyls (PCBs) and mixtures of polychlorinated dibenzo- $p$-dioxin and dibenzofuran (PCDD/PCDF) are widespread contaminants in the aquatic environment. Their lipophilicity and persistent properties could cause them to accumulate in aquatic animals and cause adverse effects. As a bioindicator, the aryl hydrocarbon-receptor (Ah-receptor) effect has been characterized in several fish species (Lorenzon and Okey, 1990; Hahn et al., 1992). The Ah-agonists effect signals the induction

\footnotetext{
*Corresponding author. Research Center for Eco-environmental Sciences, State Key Laboratory of Environmental Aquatic Chemistry, Chinese Academy of Sciences, P.O. Box. 2871, Beijing 100085, China. Fax: + 86-01-62849140.

E-mail address: wangzj@mail.rceees.ac.cn (X. Wan).

${ }^{1}$ Also for correspondence.
}

of the cytochrome P450 CYP1A monooxygenase system and is responsible for the biotransformation of many types of lipophilic xenobiotics. CYP1A-dependent enzymes induced by PAHs and polyhalogenated compounds could be assayed by enzymatic activities of EROD and Ah hydroxylase (Poland and Knutson, 1982). Among the Ah agonists, TCDD is the most toxic, and there is a good correlation between Ah-receptor affinity, toxicity, and CYP1A induction (Poland and Knutson, 1982).

EROD assays can be performed either in in vivo organ homogenate or in vitro cell culture. Compared with in vivo assay, only small quantities of xenobiotics are needed for in vitro assay. This is particularly important when studying the effects of trace pollutants in environmental samples. Although in vitro assay is not a substitute for in vivo assay, it can be used as an adjunct model to whole-animal experiments in vivo and the ecotoxicological evaluation of the potential risk of 
trace pollutants in aquatic environments. Among in vitro assays, cells isolated from intact organs can be used directly after isolation as short-term suspension cultures or be plated on the culture plates. For example, under appropriate culture conditions, the attached primary hepatocytes remain viable for at least 1 week or even up to 1 month (Pesonen and Andersson, 1997). Primary hepatocytes, both freshly isolated and cultured, generally maintain many of their in vivo characteristics, thus facilitating extrapolation of the results to those seen in in vivo situations. Also, there is evidence that fish hepatocytes in short-term primary culture maintain such metabolic pathways as glycolysis, gluconeogenesis, and lipogenesis, as well as their responsiveness to various hormones (Mommsen and Lazier, 1986; Vaillant et al., 1988; Segner et al., 1994). Cytological characterization has shown that fish hepatocytes in primary culture displayed only minor cytological alterations during the first 7 days in culture (Blair et al., 1990; Braunbeck and Storch, 1992). It is for these reasons that fish primary hepatocytes have been used to study the metabolism of xenobiotics, the formation of toxic products, chemicalinduced DNA damage, the induction of enzymes, peroxisome proliferation, and effects on hormone systems (Moon et al., 1985). The mechanisms involved in chemical-induced toxicity can be determined in more detail than would be possible in in vivo studies. Cultured hepatocytes represent a powerful, yet simple, experimental tool for the study of hepatic function in fish, and are particularly well suited for applications in the field of pharmacology and environmental toxicology.

Grass carp (Ctenopharyngodon idellus) is widespread and can be found in all aquatic environments in China. Therefore, we developed an assay approach using primary cell culture of grass carp hepatocytes. To evaluate its feasibility, EROD assay and chemical analysis for PCDD/PCDF were performed for the same environmental samples. Activities of LDH and GST in the cells were also examined.

\section{Materials and methods}

\subsection{Sampling and sample preparation}

Electrolytic waste was collected from deposition of electrolysis cells at a chlor-alkali plant in Wuhan, China. The fly ash was collected from a destructor plant in Beijing, China. The environmental reference materials of PCDD/PCDF for sediment (S38) and for soil (BCR) were provided by the European Economic Community and GSF-National Institute of Environmental Science and Health (Munich, Germany), respectively. Chlorinated choline was an industrial product obtained from Shanghai, China. Tetrachlorinated benzene quinone (TCBQ) is a chemical reagent obtained from a factory in Wuhan, China. The samples were prepared according to $\mathrm{Wu}$ (1999). After the collected samples were freezedried and pulverized, $1-5 \mathrm{~g}$ of sample was Soxhletextracted with toluene $(180 \mathrm{~mL})$ for $24 \mathrm{~h}$ and then evaporated ( $130 \mathrm{mbar}, 333 \mathrm{~K})$ to $2-3 \mathrm{~mL}$. Concentrated crude extract was applied to a column filled with hexane. The column was packed with $10 \mathrm{~g}$ silica $(44 \%$ in concentrated sulfuric acid, w/w), $40 \mathrm{~g}$ deactivated silica ( $4 \%$ in water, $w / w)$, from bottom to top. The silica type was active and $63-200 \mu \mathrm{m}$. The column was topped with $\mathrm{Na}_{2} \mathrm{SO}_{4}$; samples were then eluted by $870 \mathrm{~mL}$ hexane and the eluate evaporated $\left(500 \mathrm{mbar}, 60^{\circ} \mathrm{C}\right)$ to $2-3 \mathrm{~mL}$. The extract was transferred stepwise into a microvial and evaporated to dryness under a stream of nitrogen. Then the sample was redissolved with $500 \mu \mathrm{L}$ of a mixture of dimethyl sulfoxide (DMSO)/isopropanol (4:1 $\mathrm{v} / \mathrm{v}$ ) and stored in the dark at $4^{\circ} \mathrm{C}$ as bulk solution for the following bioassay.

\subsection{Isolation of hepatocytes}

Male grass carp weighing $1.0-1.5 \mathrm{~kg}$ were purchased from a hatchery in Wuhan, China. Hepatocytes were isolated according to the methods of Pärt et al. (1993), Smeets et al. (1999), and Pesonen and Andersson (1997), with modifications. In the procedure, a fish was cleared of blood from the tail vein with an injector, its skin was sterilized by alcohol, and its abdomen was dissected with sterile instruments from anus toward head. Liver tissue was excised and rinsed twice during $5 \mathrm{~min}$ with sterilized water and $\mathrm{a} \mathrm{Ca}^{2+}$ - and $\mathrm{Mg}^{2+}$-free buffer solution $(\mathrm{pH}$ 7.5) containing $0.145 \mathrm{M} \mathrm{NaCl}, 5.4 \mathrm{mM} \mathrm{KCl}, 5 \mathrm{mM}$ EDTA (Beijing Chemical Co.), $1.1 \mathrm{mM} \quad \mathrm{KH}_{2} \mathrm{PO}_{4}$, $12 \mathrm{mM} \mathrm{NaHCO} 3,3 \mathrm{mM} \mathrm{NaH} \mathrm{PO}_{4}, 100 \mathrm{mM}$ HEPES (Sigma). The liver tissue was then minced into pieces of $\sim 1 \mathrm{~mm}^{3}$ and transferred to a $50-\mathrm{mL}$ conical tube to which a solution of $0.25 \%$ trypsin was added $(1: 20 \mathrm{w} / \mathrm{v}$; Sigma). The mixture was trypsinized on a shaker at $200 \mathrm{rpm}$ for $5 \mathrm{~min}$ to obtain the cell suspension, which was then filtered through a 70-mesh sieve. The cell suspensions were pooled and centrifuged at $1000 \mathrm{rpm}$ for $2 \mathrm{~min}$, and the cell pellet was washed with DMEM/ F12 (Sigma) culture medium (pH 7.4) containing $14.3 \mathrm{mM} \mathrm{NaHCO} 3,20 \mathrm{mM}$ HEPES, $50 \mathrm{mg} / \mathrm{L}$ gentamicin sulfate (Amresco Company), $1 \mu \mathrm{M}$ insulin (Sigma), $10 \mu \mathrm{M}$ hydrocortisone, and $2 \% \mathrm{v} / \mathrm{v}$ FBS (Hyclone Company). The cells were resuspended in culture medium and counted. When viability was $>90 \%$ as assessed with Trypan Blue exclusion, the cells were used for experiments (Situ and $\mathrm{Wu}, 1996$ ).

\subsection{Cell culture and exposure experiment}

Hepatocytes were cultured in DMEM/F12 culture medium. Cells were seeded in 96-well culture plates at $2 \times 10^{5}$ cells $/ \mathrm{mL}$ and $200 \mu \mathrm{L}$ per well, and the plate was 
maintained in air at room temperature. Primary hepatocytes were cultured for a total of 5 days. Hepatocytes had attached to the wells and formed a monolayer of $70-80 \%$ confluence within $24 \mathrm{~h}$, and at this time the culture medium was removed and replaced with testing medium. Hepatocytes were exposed for another 4 days. During the testing period, the cells progressively aggregated to form cell strands in which cells attached more firmly to each other than to the culture plate, as also observed by Smeets et al. (1999). So as not to dislodge the cells during the medium changes, only $90 \%$ of the culture medium was removed and carefully replaced by fresh medium.

Hepatoma cell lines from rat (H4IIE) was obtained from the Cell Culture Center at Wuhan University, cultured with DMEM (Gibco Company), and used for PCDD/PCDF evaluation according to Li et al. (1998).

The culture medium was added with either extracts of environmental samples or chemicals. Eight concentration levels were used for bioassay, and the concentration sequences were obtained by two-fold dilution from bulk solution. For each concentration level, four duplicates were used on one plate. Along with each plate in measurement of environmental samples, a TCDD standard curve was run $(0-140 \mathrm{pg} / \mathrm{mL}$ and $N=8)$, and the TEQ of the sample was calculated. If necessary, the extract of the sample was diluted to fit the linear part of the TCDD dose-response curve, and the best-fitting part run at the same time was chosen to calculate the TEQ of the bulk sample. DMSO was used as solvent blank and was tested in the same manner as the samples. The final concentration of DMSO in culture medium of a bioassay did not exceed $0.5 \%$.

\subsection{Measurements of enzymatic activities}

At the end of exposure period (day 5), the culture medium was transferred into another 96-well plate for measurement of LDH activity in the supernatant. The remaining cell monolayers were used immediately for measurements of EROD, LDH, and GST activities in cells. In cases where the enzymatic activities could not be measured immediately, the cell was immediately frozen and kept at $-70^{\circ} \mathrm{C}$ prior to enzymatic measurements.

Measurements of EROD activity followed the slightly modified procedures according to Burke and Mayer (1974), Smeets et al. (1999), and Carlsson et al. (1999). The measurement was carried out directly on the 96-well plates. Before measurement, cells cultured in 96-well plates were rinsed with $50 \mathrm{mM}$ iced Tris buffer ( $\mathrm{pH}$ 7.4). Then EROD reaction mixture was added $(100 \mu \mathrm{L}$ to each well). The reaction mixture contained $50 \mathrm{mM}$ Tris buffer, $0.1 \mathrm{M} \mathrm{NaCl}, 20 \mu \mathrm{M}$ dicumarol (Karlsruhe, Germany), and $2 \mu \mathrm{M}$ ethoxyresorufin (Sigma), and $\mathrm{pH}$ was adjusted to 7.8. The reaction was allowed to proceed for $30 \mathrm{~min}$ at room temperature, and the fluorescence intensity of the resorufin was recorded at $535 \mathrm{~nm}$ (excitation) and $590 \mathrm{~nm}$ (emission) using a fluorescence multiwell plate reader (TECAN-Genios, Finland).

GST activities were measured as described by Habig and Jakoby (1981) and Willett et al. (1999). Briefly, the reaction mixture contained $0.1 \mathrm{M}$ potassium phosphate ( $\mathrm{pH}$ 6.5), $1 \mathrm{mM}$ glutathione, $1 \mathrm{mM}$ 1-chloro-2,4-nitrobenzene, $10 \mathrm{mM}$ allyl alcohol. After $5 \mathrm{~min}$ of reaction at room temperature, the absorbance at $340 \mathrm{~nm}$ was recorded with an absorbance multiwell plate reader (TECAN-Genios).

LDH activity was measured according to Brydon and Smith (1973). In the measurement, NADH and pyruvate were dissolved in $81.3 \mathrm{mM}$ Tris buffer, containing $203.3 \mathrm{mM} \mathrm{NaCl}$, and $\mathrm{pH}$ was adjusted to 7.2. To each well were added $200 \mu \mathrm{L} 0.244 \mathrm{mM}$ NADH. After incubation at $30^{\circ} \mathrm{C}, 40 \mu \mathrm{L} 9.76 \mathrm{mM}$ pyruvate was added. Absorbance was continuously recorded at $340 \mathrm{~nm}$ with an absorbance multiwell plate reader (TECAN-Genios).

The cells in multiwell plates were lysed using $0.3 \mathrm{M}$ $\mathrm{NaOH}$, and the cell lysate was used for protein analysis. In each experiment, an average protein content per well was determined according to Bradford (1976), and BSA (Gibco Company) was used as protein standard.

The enzymatic activities induced by TCDD were used as reference or positive control throughout the experiments.

\subsection{Chemical analysis}

PCDD/PCDF were analyzed using a HRGC/HRMSMIS (MAT 95s, Finnigan) following the method described by Wu (1999). Briefly, samples were Soxhletextracted and cleaned by several liquid-chromatographic purification steps. Prior to the extraction, each sample was spiked with ${ }^{13} \mathrm{C}_{12}$-labeled 2,3,7,8-substituted PCDD/PCDF standards (Cambridge Isotope Laboratories, Inc.). The identification and quantification for PCDD/PCDF were accomplished with a capillary HRGC/HRMS system. An Rtx-2330 capillary column (60 $\mathrm{mm}$ length, $0.25 \mathrm{~mm}$ internal diameter, $0.1 \mu \mathrm{m} \mathrm{df}$; Restek Company, USA) was used. The temperature program was as follows: $90^{\circ} \mathrm{C}(1.5 \mathrm{~min})$ to $180^{\circ} \mathrm{C}$ $\left(10 \mathrm{~min}, 25^{\circ} \mathrm{C} / \mathrm{min}\right)$, then to $260^{\circ} \mathrm{C}\left(30 \mathrm{~min}, 2^{\circ} \mathrm{C} / \mathrm{min}\right)$. The injector was programmed as follows: $120^{\circ} \mathrm{C}(0 \mathrm{~min})$ to $280^{\circ} \mathrm{C}\left(10 \mathrm{~min}, 12^{\circ} \mathrm{C} / \mathrm{s}\right)$, then to $300^{\circ} \mathrm{C}\left(10 \mathrm{~min}, 12^{\circ} \mathrm{C} / \mathrm{s}\right)$. The column head pressure was $100 \mathrm{kPa}$. The interface was heated at $260^{\circ} \mathrm{C}$. The PCDD/PCDF were identified by MS with EI mode by tracing $\mathrm{M}^{+},\left(\mathrm{M}^{2+}\right)^{+}$ions or the most intense ions of the isotope cluster. The measurement was conducted at high resolution $(R=10,000)$ on a Finnigan MAT 95s HRGC/HRMS system. 


\subsection{Statistics}

The data from EROD measurement were imported to a curve-fitting program $\left(y=(A-D) /\left(1+(x / C)^{B}\right)+\right.$ $D$, where $A=y$ value of lower asymptote, $B=$ relative slope of middle region, $C=x$ value at midpoint of curve, $D=y$ value of upper asymptote) and was fitted to a sigmoid curve. The value causing half the maximal level of induction $\left(\mathrm{EC}_{50}\right)$ was recorded.

\section{Results and discussion}

Dose-response relationships between EROD activity and TCDD concentration in grass carp primary hepatocytes and the rat H4IIE cell line exposed for 4 days are shown in Fig. 1. It can be seen that TCDD caused a dose-dependent induction of CYP1A activity in grass carp primary hepatocytes similar to that in the H4IIE cell line. The $\mathrm{EC}_{50}$ value for TCDD when testing primary hepatocytes was $9.7 \mathrm{pg} / \mathrm{mL}$, whereas when testing the H4IIE cell line it was $0.83 \mathrm{pg} / \mathrm{mL}$. From this study, the lower limit of detection for TCDD in the H4IIE cell line was $0.14 \mathrm{pg} / \mathrm{mL}$ and the upper limit was $4.4 \mathrm{pg} / \mathrm{mL}$. However, the comparable values in the bioassay using grass carp primary hepatocytes were 2.2 and $70 \mathrm{pg} / \mathrm{mL}$. At the highest concentration, the EROD activities of both cells dropped rapidly. Induction of CYP1A by TCDD in the H4IIE cell line is much more sensitive than that in grass carp primary hepatocytes.

In previous work, $\mathrm{EC}_{50}$ values for CYP1A induction in carp primary hepatocytes upon exposure to TCDD for 18 and $96 \mathrm{~h}$ were 8.7 and $2.0 \mathrm{pg} / \mathrm{mL}$, respectively (Smeets et al., 1999). The $\mathrm{EC}_{50}$ value for rainbow trout primary hepatocytes exposed to TCDD was $\sim 8.1 \mathrm{pg} /$ $\mathrm{mL}$ after $48 \mathrm{~h}$ (Pesonen and Andersson, 1997). In the present study, $\mathrm{EC}_{50}$ values in grass carp primary hepatocytes after $24,48,72$, and $96 \mathrm{~h}$ of exposure to
TCDD were 23.6, 21.7, 9.7, and $15.3 \mathrm{pg} / \mathrm{mL}$ (Fig. 2), respectively. Therefore, the sensitivities of primary cell cultures of different fish to TCDD were quite similar and were lower than that of the H4IIE cell line. These results suggested that mammalian cell lines such as H4IIE may have little relevance for predicting the relative potency of polyhalogenated aromatic hydrocarbons for fish (Clemons et al., 1994). Thus, a bioassay using fish hepatocytes may be more relevant for biomonitoring polyhalogenated hydrocarbons in aquatic organisms than that using mammalian cell lines.

GST activity could not be induced by TCDD in primary hepatocytes (data not shown). GST had been thought to play a physiological role in initiating the detoxification of potential toxic agents, including pharmacologically active compounds. GST catalyzes the reaction of compounds with $-\mathrm{SH}$ group, thereby neutralizing their electrophilic sites and rendering the products more soluble. Leakage of LDH in the supernatants in the cell cultures was $<10 \%$ (Fig. 1). LDH plays a role in biodegradation processes in vivo, and its activity in the supernatant of cell culture is often used as

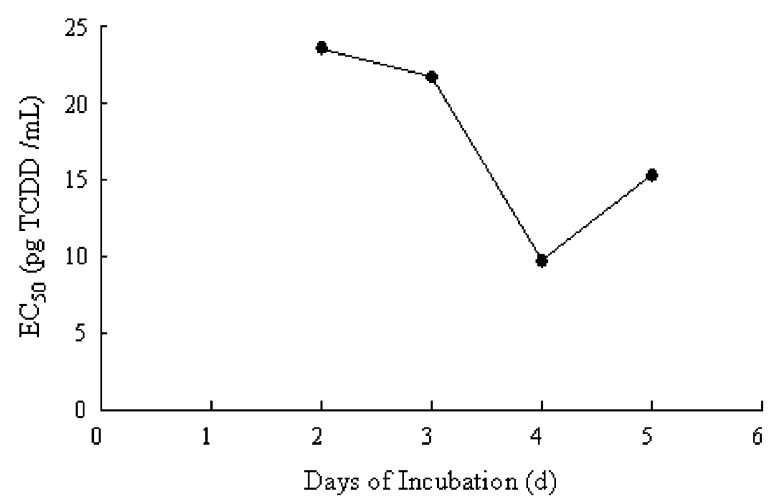

Fig. 2. $\mathrm{EC}_{50}$ values in grass carp $(C$. idellus) primary hepatocytes exposed to $1-140 \mathrm{pg} / \mathrm{mL}$ TCDD for $2-5$ days.
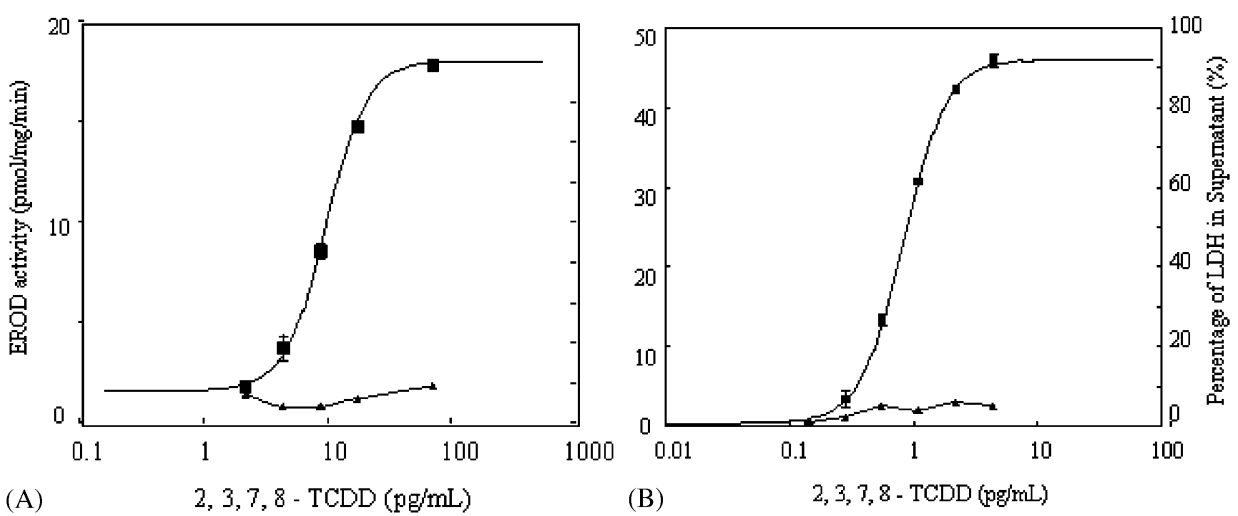

Fig. 1. Dose-response relationship between EROD activity and TCDD concentration in (A) grass carp (C. idellus) primary hepatocyte culture and (B) rat hepatoma H4IIE cell culture. ( $\diamond$ EROD induction in the cells exposed to TCDD. ( $\mathbf{\Delta}$ ) LDH leakage as percentage of total LDH in the cells. Error bars represent SD of four measurements. 
an additional indicator for cytotoxicity. The insignificant changes in the activities of both GST and LDH indicated that the biodegradation of TCDD in the fish body was possibly difficult and that cytotoxicity of TCDD was not significant under dosage levels sufficient to initiate CYP1A induction. The results from LDH measurements also showed that the primary hepatocytes remained viable throughout the experiment and thus would provide a powerful model for research in toxicology and pharmacology.

When the primary hepatocytes were exposed to TCDD for 2-5 days, the time course of the induction is shown in Fig. 2. It is known that TCDD is the most potent $\mathrm{Ah}$ agonist. One of the most sensitive responses to Ah-receptor activation is induction of CYP1A1, which can be measured as EROD activity. Grass carp hepatocytes proved to be sensitive for this response. It could be observed that $\mathrm{EC}_{50}$ values varied with exposure time (Fig. 2). The $\mathrm{EC}_{50}$ value is minimal after 4 days of exposure. However, the maximal level of induction remained constant and occurred at the dose level of $70 \mathrm{pg} / \mathrm{mL}$ TCDD (data not shown). The P450 1A induction kinetics in fish primary hepatocyte cultures, as shown in Fig. 2, were similar to that in in vivo tests with fish after a single treatment (Pesonen et al., 1992). It is possible that primary cells maintain intact characteristics of the original tissue in in vivo and many metabolic systems, including biotransformation of complex environmental matrices. The decrease of $\mathrm{EC}_{50}$ with the increase of exposure time could be caused by a progressive accumulation of lipophilic and poorly biodegradable TCDD in cells (Vaillant et al., 1988). It is probably not only the accumulation of the inducing agent that results in minimal $\mathrm{EC}_{50}$ values for $\mathrm{EROD}$ induction, but also the induction kinetics of CYP1A itself.

H4IIE cells are rich in Ah receptors and respond to a variety of $\mathrm{Ah}$ agonists. This cell line has been widely used in screening bioassays for dioxin-like pollutants in environmental samples. The bioassays based on the primary hepatocyte culture and on H4IIE cells were carried out using environmental samples and chemicals that may contain dioxin-like compounds. The data are shown in Table 1. Simultaneously, chemical analysis for PCDD/PCDF was performed by HRGC/HRMS-MIS. The results are expressed as TEQs, calculated from individual congeners of PCDD/PCDF or obtained from the calibration curve of TCDD on the same plate for EROD measurement. The results in Table 1 illustrate that, for the same sample, TEQs obtained from bioassays using cells in vitro and chemical analysis for $\mathrm{PCDD} / \mathrm{F}$ were in the same order of magnitude. However, TEQs from in vitro bioassay using H4IIE cells were slightly lower than those from chemical analysis, with the exception of that from sediment samples. Generally, there were Ah-acceptor agonists
Table 1

TEQs of environmental samples and chemicals measured HRGC/ HRMS-MID and in vitro bioassays

\begin{tabular}{llll}
\hline Sample & \multicolumn{2}{l}{ TEQs (ng/g) } \\
\cline { 2 - 4 } & $\begin{array}{l}\text { HRGC/ } \\
\text { HRMS-MIS }\end{array}$ & $\begin{array}{l}\text { Rat H4IIE } \\
\text { cells }\end{array}$ & $\begin{array}{l}\text { Grass carp primary } \\
\text { hepatocytes }\end{array}$ \\
\hline $\begin{array}{l}\text { Sediment (S38) } \\
\begin{array}{l}\text { Chlorinated } \\
\text { choline }\end{array}\end{array}$ & 0.26 & 0.39 & 0.37 \\
$\begin{array}{l}\text { Electrolytic waste } \\
\text { TCBQ }\end{array}$ & 0.71 & 0.16 & 0.18 \\
Soil (BCR) & 0.91 & 0.67 & 1.00 \\
Fly ash & 6.43 & 0.82 & 1.21 \\
\hline
\end{tabular}

other than PCDD/PCDF in the samples, such as coplanar PCBs, which contribute also to the EROD activity. Our current data could not explain the underestimation of TEQs using H4IIE cells. However, there might be some antagonists in the sample, such as in chlorinated choline (Table 1). TEQs obtained from bioassay using primary cell culture were close to those of chemical analysis (Table 1). Moreover, the results obtained from bioassays using two kinds of cells were quite comparable to each other $\left(\mathrm{EROD}_{\mathrm{H} 4 \mathrm{IIE}}\right.$ cells $=$ 1.28EROD $\left.\mathrm{E}_{\text {Primary cells }}+0.07, R=0.996\right)$ and to that of chemical analysis $\left(R_{\text {Primarycells }}=0.992, \quad R_{\mathrm{H} 4 \text { IIEcells }}=\right.$ 0.998). Considering that the bioassay using primary cell culture may reflect more realistically the potential ecological toxicity of dioxin-like compounds in aquatic systems, the proposed approach could be used to screen dioxin-like pollutants in waters and sediments.

Among those samples measured, fly ash contains more dioxin-like compounds, and TCBQ produced as an individual chemical proved to have great toxicity in this study. For standard materials of soil and sediment, both bioassays gave reasonable estimations and confirmed that the CYP1A inductions in the materials were mainly contributed by PCDD/PCDF.

\section{Conclusions}

There is dose-dependent induction of EROD activity in primary hepatocyte culture of grass carp (C. idellus), similar to that seen in rat hepatoma H4IIE cells. The results obtained from the assay using the primary culture for quantification of $\mathrm{PCDD} / \mathrm{PCDF}$ in environmental samples were comparable to those from bioassay using the H4IIE cell line and chemical analysis using HRGC/HRMS. Therefore, we conclude that the proposed primary culture bioassay offers a useful tool, or alternative, for assessing the presence of toxic dioxinlike substances in complex environmental matrices. The method based on primary hepatocyte cultures of grass carp may be developed to meet the need for rapid and 
inexpensive monitoring of dioxin-like compounds in laboratories or monitoring stations.

\section{Acknowledgments}

This project was supported by the Chinese Academy of Sciences (KZCX2-414), 863 Program of China (2001AA6406010), and the National Natural Science Foundation of China (20237010).

\section{References}

Blair, J.B., Miller, M.R., Pack, D., Barnes, R., The, S.J., Hinton, D.E., 1990. Isolated trout liver cells: establishing short-term primary cultures exhibiting cell-to-cell interactions. In Vitro Cell. Dev. Biol. 26, 237-249.

Bradford, M.M., 1976. A rapid and sensitive method for the quantification of microgram quantities of protein utilizing the principle of protein dye binding. Anal. Biochem. 72, 248-254.

Braunbeck, T., Storch, V., 1992. Senescence of hepatocytes isolated from rainbow trout (Oncorhynchus mykiss) in primary culture: an ultra-structural study. Protoplasma 170, 138-159.

Brydon, W.G., Smith, A.F., 1973. An appraisal of routine methods for the determination of the anodal isoenzymes of lactate dehydrogenase. Clin. Chim. Acta 143, 361-369.

Burke, M.D., Mayer, R.T., 1974. Ethoxyresorufin: direct fluorimetric assay of a microsomal $O$-dealkylation which is preferentially inducible by 3-methylcholanthrene. Drug Metab. Disposit. 2, 583-588.

Carlsson, C., Pärt, P., Brunström, B., 1999. 7-Ethoxyresorufin $O$ deethylase induction in cultured gill epithelial cells from rainbow trout. Aquat. Toxicol. 47, 117-128.

Clemons, J.H., van den Heuvel, M.R., Stegeman, J.J., 1994. Comparison of toxic equivalent factors for selected dioxin and furan congeners derived using fish and mammalian liver cell lines. Can. J. Fish. Aquat. Sci. 51, 1577-1584.

Habig, W.H., Jakoby, W.B., 1981. Assays for differentiation of glutathione $S$-transferase. Methods Enzymol. 77, 398-405.

Hahn, M.E., Poland, A., Glover, E., Stegeman, J.J., 1992. The ah receptor in marine animals: phylogenetic distribution and relationship to PO4501A1 inducibility. Mar. Environ. Res. 34, 87-92.

Li, W., Wu, W.Z., Schramm, K.W., Xu, Y., Yediler, A., Kettrup, A., 1998. In vitro EROD induction by mixtures of polychlorinated dibenzo-p-dioxin (PCDD), dibenzofuran (PCDF) and biphenyl
(PCB). Proceedings of the First Asian Conference on Ecotoxicology and Environmental Safety, Wuhan, China.

Lorenzon, A., Okey, A.B., 1990. Detection and characterization of [3H]2,3,7,8-tetrachlorodibenzo- $p$-dioxin binding to Ah receptor in a rainbow trout hepatoma cell line. Toxicol. Appl. Pharmacol. 106, 53-62.

Mommsen, T.P., Lazier, C.B., 1986. Stimulation of estrogen receptor accumulation by estradiol in primary cultures of salmon hepatocytes. FEBS Lett. 195, 269-271.

Moon, T.W., Walsh, P.J., Mommsen, T.P., 1985. Fish hepatocytes: a model metabolic system. Can. J. Fish. Aquat. Sci. 42, 1772-1782.

Pärt, P., Norrgren, L., Bergstöm, E., Sjöberg, P., 1993. Primary cultures of epithelial cells from rainbow trout gills. J. Exp. Biol. 175, 219-232.

Pesonen, M., Andersson, T.B., 1997. Fish primary hepatocyte culture: an important model for xenobiotic metablism and toxicity studies. Aquat. Toxicol. 37, 253-267.

Pesonen, M., Goksoyr, A., Andersson, T., 1992. Expression of P4501A1 in a primary culture of rainbow trout hepatocytes exposed to $\beta$-naphthoflavone or 2,3,7,8-tetrochlorodibenzo- $p$ dioxin. Arch. Biochem. Biophys. 292, 228-233.

Poland, A., Knutson, J.C., 1982. 2,3,7,8-tetrachlorodibenzo-p-dioxin and related halogenated aromatic hydrocarbons: examination of the mechanism of toxicity. Annu. Rev. Pharmacol. Toxicol. 22, 517-544.

Segner, H., Blair, J.N., Wirtz, G., Miller, M.R., 1994. Cultured trout liver cells: utilization of substrates and response to hormones. In Vitro Cell. Dev. Biol. 30A, 306-311.

Situ, Z.Q., Wu, J.Z., 1996. Cell Culture. World Publishing House of Books, Beijing, China.

Smeets, J.M.W., Rankouhi, T.R., Nichols, K.M., Komen, H., Kaminski, N.E., Giesy, J.P., Berg, M., 1999. In vitro vitellogenin production by carp (Cyprinus carpio) hepatocytes as a screening method for determining (anti) estrogenic activity of xenobiotics. Toxicol. Appl. Pharmacol. 157, 68-76.

Vaillant, C., Le Guellec, G., Pakdel, F., Valotaire, Y., 1988. Vitellogenin gene expression in primary culture of male rainbow trout hepatocytes. Gen. Comp. Endocrinol. 70, 284-290.

Willett, K.L., Wilson, C., Thomsen, J., Porter, W., 1999. Evidence for and against the presence of polynuclear aromatic hydrocarbon and 2,3,7,8-tetrachlorodibenzo-p-dioxin binding proteins in the marine mussels, Bathymodiolus and Modiolus modiolus. Aquat. Toxicol. 48, 51-64.

Wu, W.Z., 1999. Environmental Behavior and Ecotoxicological Impact of Persistent Organic Pollutants (POP) in Wildlife, with Special Emphasis on the Aquatic Ecosystem. Herbert Utz Verlag Wissenschaft, Munich, Germany. 